\title{
Microsporogenesis analysis validates the use of artificially tetraploidized Brachiaria ruziziensis in breeding programs
}

\author{
C.M.P. Paula ${ }^{1}$, K.G. Figueiredo ${ }^{1}$, F. Souza Sobrinho ${ }^{2}$, F.R.G. Benites ${ }^{2}$, \\ L.C. Davide ${ }^{1}$ and V.H. Techio ${ }^{1}$ \\ ${ }^{1}$ Laboratório de Citogenética, Departamento de Biologia, \\ Universidade Federal de Lavras, Lavras, MG, Brasil \\ ${ }^{2}$ Empresa Brasileira de Pesquisa Agropecuária, \\ Embrapa Gado de Leite, Juiz de Fora, MG, Brasil \\ Corresponding author: V.H. Techio \\ E-mail: vhtechio@dbi.ufla.br \\ Genet. Mol. Res. 15 (3): gmr. 15038737 \\ Received April 27, 2016 \\ Accepted June 7, 2016 \\ Published September 19, 2016 \\ DOI http://dx.doi.org/10.4238/gmr.15038737
}

Copyright (C) 2016 The Authors. This is an open-access article distributed under the terms of the Creative Commons Attribution ShareAlike (CC BY-SA) 4.0 License

\begin{abstract}
The genus Brachiaria contains species that have great economic importance in the Brazilian agricultural sector, as they enable cattle ranching on acid and poor soils with species that are resistant to spittlebugs and form crop-livestock-forest integration systems. The genus mainly consists of tetraploid $(2 \mathrm{n}=4 \mathrm{x}=36)$ and apomictic species such as $B$. decumbens and $B$. brizantha. Sexuality is found in diploid species $(2 \mathrm{n}=2 \mathrm{x}=18)$ such as $B$. ruziziensis. Interspecific hybridization between species of interest is possible by the artificial tetraploidization of $B$. ruziziensis and the subsequent hybridization with genotypes of $B$. brizantha and $B$. decumbens. Therefore, tetraploidized plants have to have normal meiosis or low rates of irregularities, as well as produce viable pollen grains. The objective of this study was to compare meiosis
\end{abstract}


and pollen grain viability and morphology in artificially tetraploidized B. ruziziensis with that of descendants generated from crossing and selfing. The frequency of meiotic abnormalities ranged from 4.43 to $11 \%$, and pollen viability ranged from 61 to $85 \%$. Abnormalities were detected from prophase I to the tetrad stage with a variable frequency between the genotypes. The meiotic behavior of the artificially tetraploidized plants was little affected, and the pollen viability of the genotypes was high. Regarding pollen grain ultrastructure, there were no variations or morphological changes in the different genotypes. The genotypes have meiotic stability and high pollen viability, and can be incorporated into Brachiaria breeding programs.

Key words: Breeding; Forage; Meiosis; Pollen grain; Polyploidy

\section{INTRODUCTION}

Brachiaria (Trinius) Grisebach [(syn. Urochloa Hochst. ex A. Rich.) R.D. Webster] is a large and diverse genus that contains approximately 100 species that are native to tropical Africa (Renvoize et al., 1996). They have great economic importance in Brazilian agriculture, originally by enabling cattle ranching on acid and poor soils (Araújo et al., 2008) and currently for containing species with resistance to spittlebugs (Souza Sobrinho et al., 2010) and forming crop-livestock-forest integration systems (Machado et al., 2011).

The current taxonomic limits of the genera Brachiaria and Urochloa are still undefined. Based on floral biology studies, a new nomenclature has been suggested for some species by including them in the genus Urochloa (Morrone and Zuloaga, 1992). However, in the absence of any contrary information, Brachiaria and Urochloa are considered synonyms in this study.

The importance of these species is demonstrated by the fact that about $85 \%$ (Macedo, 2006) of the 170 million hectare-total of cultivated pastures in the country is used to grow them (Instituto Brasileiro de Geografia e Estatística, 2006). Among them, B. brizantha (A. Rich) Stapf, B. decumbens Stapf, B. humidicola (Rendle) Schweick, and B. ruziziensis Germain and Evrard are the most commercially exploited (Valle and Pagliarini, 2009).

In addition to these aspects, a number of favorable agronomic traits has attracted attention to them as forage crops, so extensive efforts have been made to cytogenetically and genetically characterize the species for breeding. The objectives of breeding are to evaluate and select promising genotypes and efficient hybrids in terms of yield, adaptation to acid soils, nutritional value, and resistance to spittlebugs (Pereira et al., 2001; Valle et al., 2004; Souza Sobrinho, 2005). The focus of cytogenetic characterization has been the assessment of meiotic behavior and ploidy determination. The genus mainly consists of tetraploid $(2 n=4 x=36)$ and apomictic species such as $B$. decumbens and $B$. brizantha. Sexuality is found in diploid species $(2 \mathrm{n}=2 \mathrm{x}=18)$ such as B. ruziziensis (Valle et al., 1994).

One of the limitations of Brachiaria breeding is the ploidy difference between sexual and apomictic plants, which prevents crossings, generates a small number of hybrids, and causes sterility (Valle et al., 2004). To overcome this problem, a promising strategy is the artificial tetraploidization of the diploid and sexual species $B$. ruziziensis and the subsequent hybridization with tetraploid and apomictic genotypes of $B$. brizantha and $B$. decumbens (Ishigaki et al., 2009), in order to obtain genetic variability for the selection of superior

Genetics and Molecular Research 15 (3): gmr.15038737 
materials (Pereira et al., 2001; Souza Sobrinho, 2005).

Antimitotic substances, such as colchicine, which is an alkaloid that is widely used in forage species, are used in the induction of polyploidy (Pereira et al., 2012). Several duplication studies have been conducted on Brachiaria, including on seeds germinated in vivo (Swenne et al., 1981; Timbó et al., 2014) and the in vitro culture of germinated seeds, multiple shoots (Ishigaki et al., 2009), and basal segments (Pinheiro et al., 2000; Simioni and Valle, 2009). In general, successfully obtaining polyploids depends on several exogenous factors (Pereira et al., 2012), and the use of colchicine causes side effects such as sterility, abnormal growth, chromosomal loss or rearrangement, mutations (Luckett, 1989), and mixoploidy (Pereira et al., 2012). These aspects should be evaluated when analyzing the degree of plant stability.

For breeding purposes, tetraploidized plants have to exhibit normal meiosis or low irregularity rates. The assessment of meiosis in tetraploidized accessions of B. ruziziensis (Risso-Pascotto et al., 2005a; Pagliarini et al., 2008) has revealed numerous abnormalities that are mainly related to irregular segregation. Furthermore, meiotic behavior is genotype-specific.

Although tetraploidized $B$. ruziziensis plants have been used as female parents in crosses with B. decumbens and B. brizantha (Souza Sobrinho et al., 2009), knowledge of the regularity of male meiosis and the production of viable pollen grains is of interest, because it provides information about the viability of intraspecific crosses, which is useful for the continued breeding of artificially tetraploidized plant populations.

The objective of this study was to comparatively evaluate the viability and morphology of pollen grains and meiosis in the 'Iracema' genotype of artificially tetraploidized B. ruziziensis plants (Timbó et al., 2014), in a B. ruziziensis genotype derived from the intercrossing of these tetraploidized plants, and in genotypes formed from the selfing of tetraploidized plants.

\section{MATERIAL AND METHODS}

\section{Plant materials}

The study was conducted using a $B$. ruziziensis genotype that had been artificially tetraploidized using colchicine $(2 \mathrm{n}=4 \mathrm{x}=36)$ ('Iracema'; Timbó et al., 2014), a genotype of $B$. ruziziensis derived from a population obtained from the intercrossing of eight tetraploidized plants ('45'), and four genotypes obtained from selfing the tetraploidized B. ruziziensis plants ('1846', '1847', '1880', and '1881'). These genotypes are part of a B. ruziziensis breeding program that is run by Embrapa Dairy Cattle, Juiz de Fora, Minas Gerais State, Brazil.

\section{Meiotic analysis and pollen viability}

Inflorescences were collected at all developmental stages, fixed in Carnoy's solution (three parts ethanol to one part acetic acid), and stored at $4^{\circ} \mathrm{C}$ until analysis.

For the meiotic analysis, anthers were removed from the inflorescences and slides were prepared by the squash technique and stained with $0.5 \%$ propionic carmine. The slides were evaluated under a bright-field microscope Carl Zeiss Axio LabA1 (Oberkochen, Germany), and meiotic behavior was assessed at all stages of microsporogenesis in at least 1000 meiocytes per genotype.

For pollen viability, the procedures used were similar to those for the meiotic analysis, except that we used a stain according to Alexander (1980). After $24 \mathrm{~h}$ of exposure to the stain,

Genetics and Molecular Research 15 (3): gmr.15038737 
1000 pollen grains per genotype were counted. Pollen grains were considered viable if they were purple and without deformities, and inviable if they were stained green. The percentage of viable pollen was then calculated.

\section{Scanning electron microscopy}

The inflorescences that had been fixed in Carnoy's solution (three parts ethanol to one part acetic acid) were washed three times for $10 \mathrm{~min}$ in cacodylate buffer and post-fixed in osmium tetroxide for $1 \mathrm{~h}$ at room temperature. The anthers were then washed three times in distilled water and dehydrated in an acetone gradient $(25,50,75,90$, and $100 \%$ for 10 min each). Subsequently, they were subjected to critical point drying (Bal-Tec CPD 030, Schalksmühle, Germany). Upon completion of the drying, with the aid of a stereomicroscope, the anthers were cut in order to release the pollen grains, which were mounted on stubs and sputter-coated with gold (Bal-Tec SCD 050, Schalksmühle, Germany). The analyses were performed using a LEO EVO ${ }^{\circledR} 40$ scanning electron microscope (Carl Zeiss AG Oberkochen, Germany), and the pollen grains' morphology was classified based on Erdtman (1986).

\section{RESULTS}

The analysis of meiotic behavior confirmed the maintenance of tetraploidy $(2 \mathrm{n}=4 \mathrm{x}$ $=36$ ) in all genotypes. The frequency of meiotic abnormalities ranged from 4.43 to $11 \%$, and pollen viability ranged from 61 to $85 \%$ (Table 1). Abnormalities were observed from prophase I to the tetrad stage (Table 1) at variable frequencies in the genotypes.

Table 1. Number of cells analyzed, percentage (in parentheses) of abnormal cells at each meiotic stage, and pollen grain viability in tetraploidized genotypes of Brachiaria ruziziensis.

\begin{tabular}{|c|c|c|c|c|c|c|}
\hline \multirow[t]{2}{*}{ Stage } & \multicolumn{6}{|c|}{ Genotype } \\
\hline & Iracema & 45 & 1846 & 1847 & 1880 & 1881 \\
\hline PI & $672(11.5)$ & $697(7.5)$ & $277(0.0)$ & $664(8.7)$ & $515(0.0)$ & $858(4.4)$ \\
\hline MI & $366(28.7)$ & 134 (15.7) & $200(20)$ & $314(19.7)$ & $329(16.7)$ & $253(11.1)$ \\
\hline $\mathrm{AI}$ & $28(0.0)$ & $16(0.0)$ & $46(30.4)$ & $11(0.0)$ & $16(31.3)$ & $22(0.0)$ \\
\hline TI & $277(0.0)$ & $75(26.7)$ & $171(11.7)$ & $104(0.0)$ & $86(11.6)$ & $136(0.0)$ \\
\hline PII & $171(0.0)$ & $63(0.0)$ & $119(0.0)$ & $116(0.0)$ & $116(0.0)$ & $200(0.0)$ \\
\hline MII & $180(22.2)$ & $99(18.2)$ & $100(24)$ & $69(0.0)$ & $67(14.93)$ & $130(10.0)$ \\
\hline AII & $24(0.0)$ & $7(0.0)$ & $33(0.0)$ & $13(0.0)$ & $16(18.8)$ & $34(0.0)$ \\
\hline TII & $87(0.0)$ & $97(8.2)$ & $64(11)$ & $158(0.0)$ & $58(0.0)$ & $114(0.0)$ \\
\hline Tet & $295(3.05)$ & $223(3.59)$ & $208(11.06)$ & $283(3.18)$ & $258(4.26)$ & $328(4.0)$ \\
\hline Total number of cells analyzed (Percentage of abnormalities/genotype) & $2100(11.0)$ & $1411(9.0)$ & $1218(10.51)$ & $1732(7.5)$ & $1461(6.43)$ & 2075 (4.43) \\
\hline Pollen viability (\%) & 85 & 80 & 61 & 77 & 84 & 73 \\
\hline
\end{tabular}

PI, prophase I; MI, metaphase I; AI, anaphase I; TI, telophase I; PII, prophase II; MII, metaphase II; AII, anaphase II; TII, telophase II; Tet, tetrad.

The genotype 'Iracema' had the highest rate of abnormalities (11\%); however, its percentage of pollen viability was high (85\%) (Table 1). The abnormalities observed in 'Iracema' were mainly detected at meiosis I, with the formation of multivalents at diakinesis (11.5\%) and non-oriented chromosomes at metaphase I (28.7\%). At meiosis II, abnormalities were found at metaphase II (22.2\%) and micronuclei were observed at the tetrad stage (3.05\%) (Table 1 and Figure 1).

Genetics and Molecular Research 15 (3): gmr.15038737 


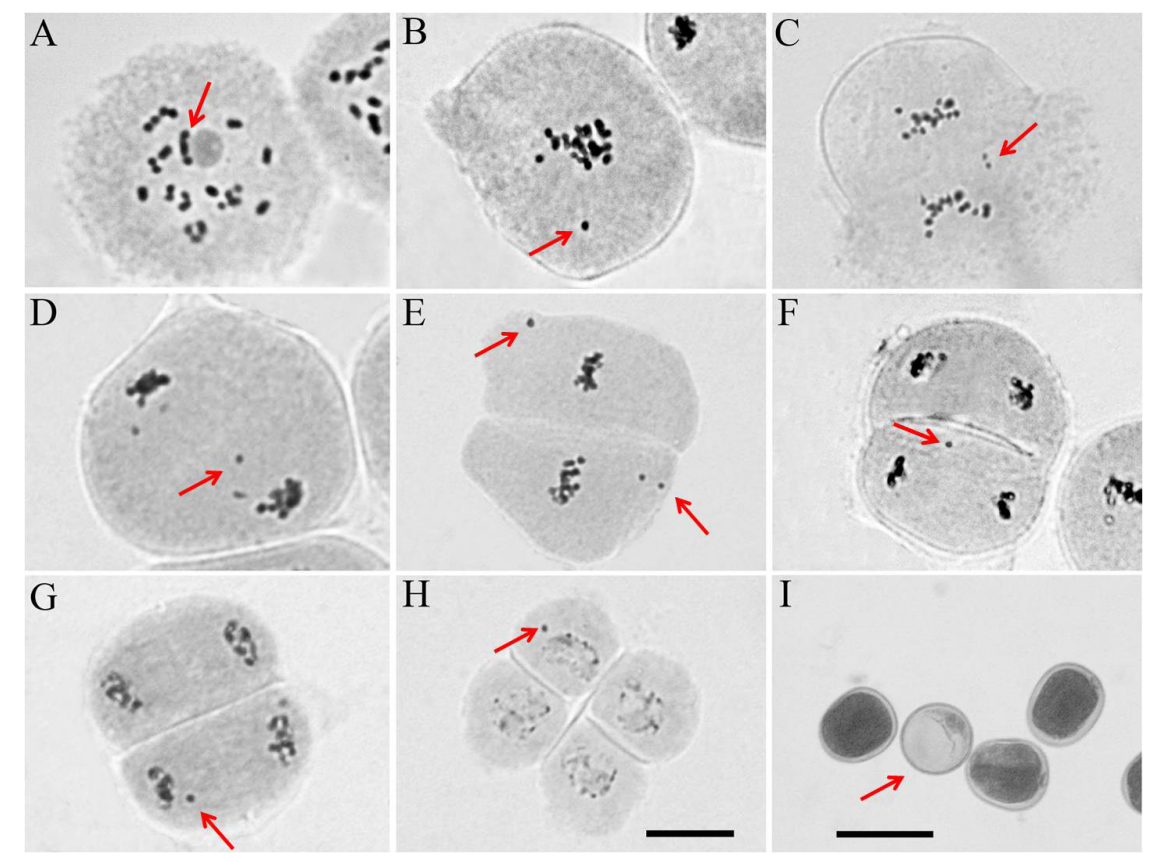

Figure 1. Meiotic abnormalities found in artificially tetraploidized Brachiaria ruziziensis plants. A. Diakinesis with multivalent (arrow). B. Metaphase I with non-oriented chromosome on the metaphase plate (arrow). C. Delayed chromosomes at anaphase I (arrow). D. Delayed chromosomes at telophase I (arrow). E. Metaphase II with non-oriented chromosomes on the plate (arrow). F. Delayed chromosomes/chromatids at anaphase II (arrow). G. Micronucleus at telophase II. H. Micronucleus in tetrad; the bar represents $20 \mu \mathrm{m}$. (I) Viable and inviable pollen grains (arrow); the bar represents $50 \mu \mathrm{m}$.

Genotype ' 45 ', which resulted from intercrossing eight tetraploidized plants, had 9\% meiotic abnormalities and $80 \%$ pollen viability (Table 1). Multivalent configurations were observed in about $7 \%$ of the 697 cells analyzed. We also observed non-oriented chromosomes at metaphase I (15.7\%) and II (18.2\%), delayed chromosomes/chromatids at telophase I (26.7\%) and II (8.2\%), and micronuclei in the tetrad stage (3.59\%) (Table 1 and Figure 1).

In genotype ' 1846 ', which resulted from selfing tetraploidized B. ruziziensis plants, abnormalities (10.51\%) extended from metaphase I to the tetrad stage (Table 1), and the pollen viability was $61 \%$. Abnormalities in the orientation of chromosomes and chromatids at metaphases I and II were recorded in 20 and 24\%, respectively, of the cells examined, and chromosomes with irregular segregation were quantified at a frequency of $30.4 \%$ at anaphase I. At telophase II and the tetrad stage, irregularities were detected in approximately $11 \%$ of the meiocytes analyzed (Table 1 and Figure 1).

The other three genotypes ('1847', '1880', and '1881'), which were also derived from selfing tetraploidized B. ruziziensis plants, had $7.5,6.43$, and $4.43 \%$ abnormalities, respectively, and 77,84 , and $73 \%$ pollen viability, respectively. In genotype ' 1847 ', abnormalities were observed at prophase I, with a multivalent formation at diakinesis in $8.7 \%$ of the meiocytes; at metaphase I, with non-oriented chromosomes in $19.7 \%$ of the meiocytes; and in the tetrad stage, with micronuclei in $3.18 \%$ of the meiocytes (Table 1 and Figure 1). In genotype '1880', 
the main meiotic abnormalities were related to irregular orientation and the segregation of chromosomes/chromatids at metaphases I (16.7\%) and II (14.93\%), anaphases I (31.3\%) and II (18.8\%), and telophase I (11.6\%), resulting in the formation of micronuclei in the tetrads (4.26\%) (Table 1 and Figure 1). In genotype ' 1881 ', 4.4\% of the meiocytes at diakinesis exhibited multivalent pairing, 11 and $10 \%$ of metaphases I and II, respectively, exhibited non-oriented chromosomes/chromatids on the equatorial plate, and $4 \%$ of the tetrads had micronuclei (Table 1 and Figure 1).

Regarding the pollen grain ultrastructure, the pollen grain aperture was classified as rounded, with a circular ambit that was located in the polar region, and was ulcerate and monoaperturate (Figure 2A and $\mathrm{B}$ ). In terms of ornamentation, the exine was psilate to scabrate (Figure $2 \mathrm{C}$ and $\mathrm{D}$ ). There were no variations or morphological changes in the different genotypes studied.

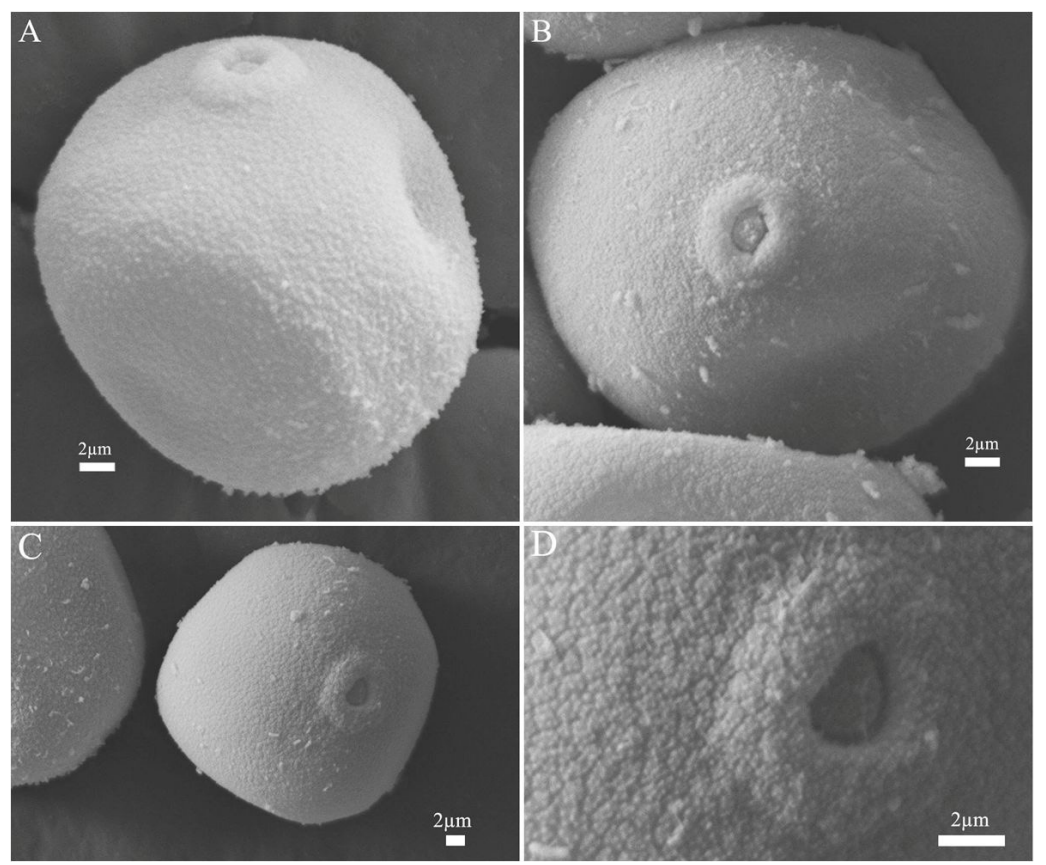

Figure 2. Pollen grains of genotype ' 45 ' in equatorial (A) and polar (B) view. Exine ornamentation of genotype ' 45 ', which was characterized as psilate to scabrate (C and D).

\section{DISCUSSION}

Our observations corroborate those in other species of Brachiaria, which have revealed that most have meiotic abnormalities, particularly those related to irregular chromosome segregation (Mendes-Bonato et al., 2002a, 2006a; Risso-Pascotto et al., 2003, 2006; Pagliarini et al., 2008). Nevertheless, the meiotic behavior of artificially tetraploidized plants in this study was little affected when compared to the $B$. ruziziensis plants examined by Risso-Pascotto et al. (2005a), which exhibited abnormalities in more than $50 \%$ of the meiocytes. Pagliarini et al. (2008) reported a low frequency of meiotic abnormalities (5.2 to 9.7\%) in five accessions of artificially tetraploidized B. ruziziensis plants. 
The percentage of abnormalities observed in this study is similar to that found by Pagliarini et al. (2008) in diploid accessions of B. ruziziensis, who reported that the mean value of abnormalities per accession varied from zero to $24.46 \%$. This suggests that artificial tetraploidization had no drastic effects on microsporogenesis in the genotypes evaluated.

Even with a frequency of abnormalities that exceeded that of its offspring (11\%), the 'Iracema' genotype had high pollen viability $(85 \%)$. There are several explanations for this result. One is that non-oriented chromosomes/chromatids, or those with irregular segregations that reached the poles of the cell at an early or late stage, may have been included in the nuclei in telophase II and the tetrad stage, where they formed normal meiotic products. Another possibility is that meiocytes with a high rate of abnormalities undergo apoptosis, which could be a strategy to eliminate non-functional pollen grains. Evidence of scheduled cell death during microsporogenesis has been found in B. brizantha (Daniela et al., 2005) and in a hybrid of artificially tetraploidized B. ruziziensis and B. brizantha plants (Fuzinatto et al., 2007a). In both cases, the effects were dramatic and resulted in male sterility (Daniela et al., 2005; Fuzinatto et al., 2007a). The high pollen viability and absence of events indicating apoptosis, such as condensed or fragmented nuclei and degenerated microspores, support the first explanation.

The observation of non-oriented chromosomes at metaphase I with different frequencies in the genotypes of tetraploidized B. ruziziensis plants may have resulted in the univalents observed at diakinesis, which usually have irregular orientation and segregation. If these chromosomes were not incorporated into the dividing nuclei, they may have been responsible for the formation of micronuclei at the telophase and tetrad stages. Irregular chromosome segregation has also been reported in accessions of artificially tetraploidized $B$. ruziziensis plants (Risso-Pascotto et al., 2005a; Pagliarini et al., 2008), and typical polyploid abnormalities have been reported in other species of Brachiaria, including $B$. decumbens (Mendes-Bonato et al., 2002b), B. brizantha (Mendes-Bonato et al., 2002a), B. jubata (Mendes-Bonato et al., 2006a), and interspecific hybrids (Risso-Pascotto et al., 2005b; MendesBonato et al., 2006b). According to Mendes-Bonato et al. (2009), the frequency of irregular chromosome segregation varies among accessions and species, and the same authors reported the formation of polyads with unbalanced microspores at the end of meiosis in tetraploidized genotypes of Brachiaria (Mendes-Bonato et al., 2009). Similarly, in artificially tetraploidized B. ruziziensis plants, Risso-Pascotto et al. (2005a) reported several abnormalities related to genome fractionation, multiple spindles, and cellularization, which resulted in the formation of polyads. The genotypes evaluated in this study did not exhibit these types of abnormalities in the tetrads. Despite the occurrence of irregular segregation and the formation of micronuclei in the tetrads, the high viability of the pollen grains indicates the formation of balanced gametes.

The pollen viability of the genotypes was high (except for genotype '1846'), and ranged between 73 and $85 \%$. Souza et al. (2002) stated that pollen viability is considered high if above $70 \%$. Therefore, according to Souza et al. (2002), the pollen grain viability of genotype ' 1846 ' was low (61\%). Although this value is higher than that obtained by Risso-Pascotto et al. (2005a) in tetraploidized B. ruziziensis plants (38.6\%), successful crossings partly depend on fertile pollen grain donors. In hybridizations using accessions of tetraploidized B. ruziziensis plants with a high percentage of meiotic abnormalities, the hybrids also exhibited a high frequency of abnormalities and could not be advanced to cultivar development (Fuzinatto et al., 2007b; Adamowski et al., 2008). Therefore, among all of the plants evaluated in this study, genotype ' 1846 ' should be the least likely to be used as a male parent in breeding programs.

Genetics and Molecular Research 15 (3): gmr.15038737 
Considering pollen grain ultrastructure, the artificially tetraploidized B. ruziziensis genotypes exhibited no change in external morphology, i.e., the induction of chromosome doubling using colchicine caused no secondary effects. The degree of plant complexity can be measured by the number of apertures (colpi) in the pollen grain, because a large number of colpi increases the probability of the successful emergence of the pollen tube, and consequently increases the probability of fertilization (Miranda and Andrade, 1990). Similarly, exines with perforated ornamentation facilitate more efficient pollination strategies (Rudall, 1980; Miranda and Andrade, 1990). However, the tetraploidized Brachiaria species only had one aperture (monoaperturate) in the polar region, and the exine did not exhibit perforated ornamentation according to the classification proposed by Erdtman (1986). Pollen grain characterization and viability assessment can supplement basic biological data that characterize genotypes and support taxonomic and evolutionary studies.

In conclusion, successful duplication and the occurrence of abnormalities varied between genotypes and species, indicating that the genotypes evaluated exhibited meiotic stability and high pollen viability, and can be incorporated into Brachiaria breeding programs. These genotypes can be used as parents in crosses with other compatible genotypes carrying desirable agronomic traits. Regarding pollen grain ultrastructure, no variations or morphological changes were observed in the different genotypes.

\section{Conflicts of interest}

The authors declare no conflicts of interest.

\section{ACKNOWLEDGMENTS}

We thank the Electron Microscopy Laboratory of UFLA for assistance in the ultrastructural analysis of the pollen grains, and Coordenação de Aperfeiçoamento de Pessoal de Nível Superior (CAPES), Conselho Nacional de Desenvolvimento Científico e Tecnológico $(\mathrm{CNPq})$, and Fundação de Amparo à Pesquisa do Estado de Minas Gerais (FAPEMIG) for financial support.

\section{REFERENCES}

Adamowski EdeV, Pagliarini MS and do Valle CB (2008). Meiotic behaviour in three interspecific three-way hybrids between Brachiaria ruziziensis and B. brizantha (Poaceae: Paniceae). J. Genet. 87: 33-38. http://dx.doi.org/10.1007/ s12041-008-0005-7

Alexander MP (1980). A versatile stain for pollen fungi, yeast and bacteria. Stain Technol. 55: 13-18. http://dx.doi. org $10.3109 / 10520298009067890$

Araújo SAC, Deminicis BB and Campos PRSS (2008). Melhoramento genético de plantas forrageiras tropicais no Brasil. Arch. Zootec. 57: 61-76.

Daniela MV, Mendes-Bonato AB, Pagliarini MS and Valle CB (2005). Abnormal meiotic behavior in Brachiaria brizantha (Poaceae) leading to microspore degeneration. Caryologia 58: 396-402. http://dx.doi.org/10.1080/0008 $\underline{7114.2005 .10589479}$

Erdtman G (1986). Pollen morphology and plant taxonomy: angiosperms. E. J. Brill, Netherlands.

Fuzinatto VA, Pagliarini MS and Valle CB (2007a). Evidence of programmed cell death during microsporogenesis in an interspecific Brachiaria (Poaceae: Panicoideae: Paniceae) hybrid. Genet. Mol. Res. 6: 308-315.

Fuzinatto VA, Pagliarini MS and Valle CB (2007b). Microsporogenesis in sexual Brachiaria hybrids (Poaceae). Genet. Mol. Res. 6: 1107-1117.

Genetics and Molecular Research 15 (3): gmr.15038737 
Instituto Brasileiro de Geografia e Estatística (2006). Censo agropecuário 2006: Brasil, grandes regiões e unidades da federação. IBGE, Rio de Janeiro.

Ishigaki G, Gondo T, Suenaga K and Akashi R (2009). Induction of tetraploid ruzigrass (Brachiaria ruziziensis) plants by colchicine treatment of in vitro multiple-shoot clumps and seedlings. Grassland Sci. 55: 164-170. http://dx.doi. org/10.1111/j.1744-697X.2009.00153.X

Luckett D (1989). Colchicine mutagenesis is associated with substantial heritable variation in cotton. Euphytica 42: 177182. http://dx.doi.org/10.1007/BF00042630

Macedo MCM (2006). Aspectos edáficos relacionados com a de Brachiaria brizantha cultivar Marandu. In: Morte de pastos de braquiárias (Barbosa RA, ed.). Embrapa Gado de Corte, Campo Grande, 35-65.

Machado LAZ, Balbino LC and Ceccon G (2011). Integração lavoura-pecuária-floresta: 1. estruturação dos sistemas de integração lavoura-pecuária. Embrapa Agropecuária Oeste, Dourados.

Mendes-Bonato AB, Pagliarini MS, Forli F, Valle CB, et al. (2002a). Chromosome number and microsporogenesis in Brachiaria brizantha (Gramineae). Euphytica 125: 419-425. http://dx.doi.org/10.1023/A:1016026027724

Mendes-Bonato AB, Filho RG, Pagliarini MS, Borges Do Valle C, et al. (2002b). Unusual cytological patterns of microsporogenesis in Brachiaria decumbens: abnormalities in spindle and defective cytokinesis causing precocious cellularization. Cell Biol. Int. 26: 641-646. http://dx.doi.org/10.1006/cbir.2002.0929

Mendes-Bonato AB, Risso-Pascotto C, Pagliarini MS and Valle CB (2006a). Chromosome number and meiotic behaviour in Brachiaria jubata (Gramineae). J. Genet. 85: 83-87. http://dx.doi.org/10.1007/BF02728976

Mendes-Bonato AB, Pagliarini MS and Valle CB (2006b). Abnormal spindle orientation during microsporogenesis in an interspecific Brachiaria (Gramineae) hybrid. Genet. Mol. Biol. 29: 122-125. http://dx.doi.org/10.1590/S1415$\underline{47572006000100023}$

Mendes-Bonato AB, Ferrari Felismino M, Souza Kaneshima AM, Pessim C, et al. (2009). Abnormal meiosis in tetraploid genotypes of Brachiaria brizantha (Poaceae) induced by colchicine: its implications for breeding. J. Appl. Genet. 50: 83-87. http://dx.doi.org/10.1007/BF03195658

Miranda MMB and Andrade TA (1990). Fundamentos de palinologia. UFC, Fortaleza.

Morrone O and Zuloaga FO (1992). Revisión de las especies sudamericanas nativas e introducidas de los géneros Brachiaria y Urochloa (Poaceae: Panicoideae: Paniceae). Darwiniana 31: 43-109.

Pagliarini MS, Risso-Pascotto C, Souza-Kaneshima AM and Valle CB (2008). Analysis of meiotic behavior in selecting potential genitors among diploid and artificially induced tetraploid accessions of Brachiaria ruziziensis (Poaceae). Euphytica 164: 181-187. http://dx.doi.org/10.1007/s10681-008-9697-2

Pereira AV, Valle CB, Ferreira RP and Miles JW (2001). Melhoramento de forrageiras tropicais. In: Recursos genéticos e melhoramento de plantas (Nass LL, Valois ACC, Melo IS and Inglis MCV, eds.). Fundação Mato Grosso, Cuiabá, 549-602.

Pereira RC, Davide LC, Techio VH and Timbó ALO (2012). Duplicação cromossômica de gramíneas forrageiras: uma alternativa para programas de melhoramento genético. Cienc. Rural 42: 1278-1285. http://dx.doi.org/10.1590/ S0103-84782012000700023

Pinheiro AA, Pozzobon MT, Valle CB, Penteado MIO, et al. (2000). Duplication of the chromosome number of diploid Brachiaria brizantha plants using colchicines. Plant Cell Rep. 19:274-278. http://dx.doi.org/10.1007/s002990050011

Renvoize SA, Clayton WD and Kabuye CHS (1996). Morphology, taxonomy and natural distribution of Brachiaria (Trin.) Griseb. In: Brachiaria: Biology, agronomy, and improvement (Miles JW, Maass BL and Valle CB, eds.). CIAT, Colombia, 1-15.

Risso-Pascotto C, Pagliarini MS, Valle CB and Mendes-Bonato AB (2003). Chromosome number and microsporogenesis in pentaploid accession of Brachiaria brizantha (Gramineae). Plant Breed. 122: 136-140. http://dx.doi.org/10.1046/ j.1439-0523.2003.00825.x

Risso-Pascotto C, Pagliarini MS and do Valle CB (2005a). Multiple spindles and cellularization during microsporogenesis in an artificially induced tetraploid accession of Brachiaria ruziziensis (Gramineae). Plant Cell Rep. 23: 522-527. http://dx.doi.org/10.1007/s00299-004-0867-y

Risso-Pascotto C, Pagliarini MS and Valle CB (2005b). Meiotic behavior in interspecific hybrids between Brachiaria ruziziensis and Brachiaria brizantha (Poaceae). Euphytica 145: 155-159. http://dx.doi.org/10.1007/s10681-005$\underline{0893-\mathrm{Z}}$

Risso-Pascotto C, Pagliarini MS and Valle CB (2006). Microsporogenesis in Brachiaria dictyoneura (Fig. \& De Not.) Stapf (Poaceae: Paniceae). Genet. Mol. Res. 5: 837-845.

Rudall P (1980). Pollen morphology in the subtribe Hyptidinae (Labiatae). Kew Bull. 35: 453-458. http://dx.doi. org/10.2307/4110014

Simioni C and Valle CB (2009). Chromosome duplication in Brachiaria (A. Rich.) Stapf allows intraspecific crosses.

Genetics and Molecular Research 15 (3): gmr.15038737 
Crop Breed. Appl. Biotechnol. 9: 328-334. http://dx.doi.org/10.12702/1984-7033.v09n04a07

Souza MM, Pereira TNS and Martins ER (2002). Microsporogênese e microgametogênese associadas ao tamanho do botão floral e da antera, e viabilidade polínica em maracujá amarelo (Passiflora edulis f. flavicarpa Degener). Cienc. Agrotec. 26: 1209-1217.

Souza Sobrinho F (2005). Melhoramento de forrageiras no Brasil. In: Forragicultura e Pastagens: Temas em evidência. Editora UFLA, Lavras, 65-120.

Souza Sobrinho F, Lédo FJS, Kopp MM, Pereira AV, et al. (2009). Melhoramento de gramíneas forrageiras na Embrapa Gado de Leite. In: Forragicultura e pastagem (Evangelista AR and Souza FF, eds.). UFLA, Lavras, 98-111.

Souza Sobrinho F, Auad AM and Lédo FJS (2010). Genetic variability in Brachiaria ruziziensis for resistance to spittlebugs. Crop Breed. Appl. Biotechnol. 10: 83-88. http://dx.doi.org/10.12702/1984-7033.v10n01a11

Swenne A, Louant B and Durjardin M (1981). Induction par la colchicine de formes autotetraploïdes chez Brachiaria ruziziensis Germain et Evrard (Graminée). Agron. Trop. 36: 134-141.

Timbó ALO, Souza PNC, Pereira RC, Nunes JD, et al. (2014). Obtaining tetraploid plants of ruzigrass (Brachiaria ruziziensis). Rev. Bras. Zootec. 43: 127-131. http://dx.doi.org/10.1590/S1516-35982014000300004

Valle CB and Pagliarini MS (2009). Biology, cytogenetics, and breeding of Brachiaria. In: Genetic resources, chromosome engineering and crop improvement (Singh RJ, ed.). CRC, Boca Raton, 103-115.

Valle CB, Glienke C and Leguisamon GOC (1994). Inheritance of apomixis in Brachiaria, a tropical forage grass. Apomixis Newsletter 7: 42-43.

Valle CB, Bonato ALV, Pagliarini MS, Resende RMS, et al. (2004). Apomixia e sua utilização no melhoramento de Brachiaria. In: Clonagem de plantas por sementes: estratégias de estudo da apomixia (Carneiro VTC and Dusi DMA, eds.). Embrapa Recursos Genéticos e Biotecnologia, Brasília, 47-65.

Genetics and Molecular Research 15 (3): gmr.15038737 